\title{
Nigerian Oil Palm Industry as a Sustainable Renewable Energy Resource
}

\author{
Felix Ishola ${ }^{1, *}$, Olumide Towoju ${ }^{2}$, Angela Mamudu $^{3}$, Obafemi Olatunji ${ }^{4}$, Stephen Akinlabi ${ }^{1,5}$ and Joana Oladejo ${ }^{6}$ \\ ${ }^{1}$ Department of Mechanical Engineering, Covenant University, Ota, 112233, Nigeria. \\ ${ }^{2}$ Department of Mechanical Engineering, Adeleke University, Ede, Nigeria. \\ ${ }^{3}$ Department of Chemical Engineering, Covenant University, Ota, 112233, Nigeria. \\ ${ }^{4}$ Department of Mechanical Engineering Science, University of Johannesburg, Johannesburg 2006, South Africa. \\ ${ }^{5}$ Department of Mechanical Engineering, Walter Sisulu University, East London 5200, South Africa. \\ ${ }^{6}$ Department of Agric Economics and Extension, Ladoke Akintola University of Technology, Ogbomoso, Nigeria.
}

\begin{abstract}
Nigeria had been standing aloof at exploring her bioresources as a means of combatting her energy cum economic challenges. After some critical examination, the authors showcased Nigerian Palm Industry as a viable biofuel source yet unexplored. Using a combination of some economic and vegetation facts and figures to comparatively analyse, Nigerian oil palm industry to validate the prospect of a sustainable commercial-scale biofuel production that can serve as both affordable alternative cleaner energy fuel for her populace and immense export revenue. The Nigerian government is encouraged to latch onto this bioresource prospect.
\end{abstract}

\section{Introduction}

The limitations of the existing fossil fuels, which include depletion in the global petroleum reserves, continuous environmental pollution and unpredictability in its political and economical oil market have led to a pursuit of suitable alternatives in biofuel [1]. More often than not, journey into any developmental exploration begins by adopting laws and guidelines in specific proposed aims and objectives unanimously agreed upon by experts, policymakers and other stakeholders [2]. Positive steps towards reducing the carbon footprint have been a daunting task for government, researchers, professionals and all downstream stakeholders [3] [4].

In the case of biofuel policies in Nigeria, a little part of the National Energy Policy (NEP) developed by the Energy Commission of Nigeria (ECN) in the year 2003 addressed the promotion of biomass energy resources [5]. However, August 2005 marked the first time the Nigerian government made a convincing move towards the development of biofuel industry with the establishment of a Renewable Energy Division (RED) under Nigeria National Petroleum Commission (NNPC) to pioneer and coordinated the development of the automotive biofuel industry in Nigeria. [6]. There and then, an official gazette document was released to highlight the road map to a gainful launch at the national biofuel industry. As deduced from the 2005 blueprint, the primary goal of the program was to help Nigeria as a country to strive on a low-carbon economy which was expected to produce incentives like additional revenue, employment, reduction in energy poverty as well as carbon footprint reduction. This guideline invariably led to a more specific policy called the Nigerian Biofuel Policy and Incentives (NBPI) in the year 2007 [7]. The implementation of the NBPI was designed to be in two phases. The first phase which was meant to be the first three years of market seeding, with plans to introduce bio-fuel into the domestic market. The was expected to penetrate some selected cities and then spread to other parts of the country within 5 to 10 years. Phase 2 was the biofuel production program, planned to kickstart at the same time as the market seeding. Implementation of the second stage was the integration program for outgrowers to meet up with feedstock production as well as the construction of biofuel plants in Nigeria. Critical observation had revealed that all the policy had never experienced a full implementation as commercial-scale biofuel production had not been apparent in Nigeria [8].

\section{A need for further Biofuel drive for Nigeria future energy demand}

Energy is one of the essential social amenity that plays a crucial role in the socio-economic development of a country, and its demand has a direct link with the improving standard and quality of life of a populace [9].

Corresponding author: felix.ishola@ covenantuniversity.edu.ng 


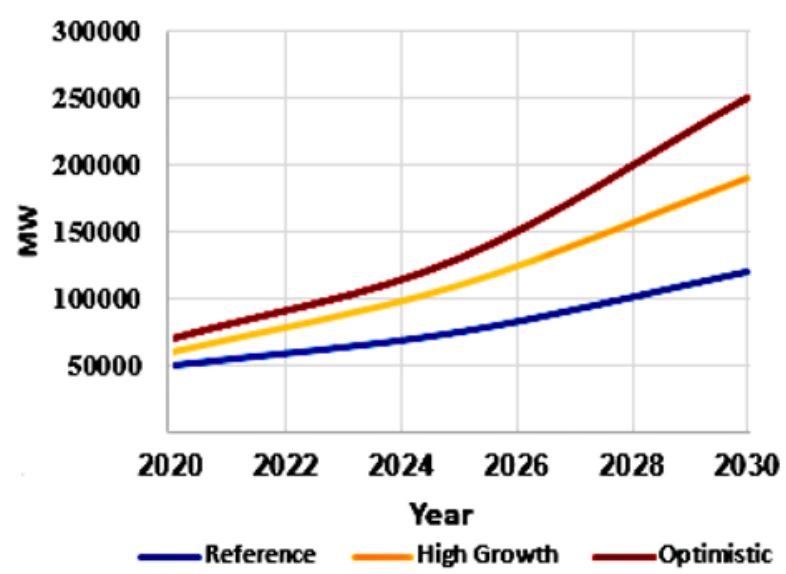

Fig. 1. Total Energy demand projections for Nigeria (using ; Reference, High-growth and Optimistic economic growth scenarios) [10].

Figure 1 indicated that total Nigerian energy demand had been projected to be on a geometrical increase over the years. The Nigerian energy demand forecast is similar to the global pattern which indicates that the road transport sector is to increase by $50 \%$ by 2030 and $80 \%$ by 2050 . Presently, fossil fuels account for about $94 \%$ of total energy demand in the transport sector and nearly three quarters are in road transport [11]. The rapid dwindling rate of the world fossil energy reserves has continued to be unmatched by discoveries. However, the comfortable existence of the present age mankind has been tailored towards his significant dependence on generated energy used in transportation from a location to another (air, land, and marine), powering of construction and agricultural equipment, and for electricity generation utilized in powering of household equipment and industrial machines/ equipment [12]

According to Emodi (2016), the vehicles in the transport sector of Nigeria would have been consuming about 581 PJ of energy by 2040 . The forecast indicated passenger car fleet to be responsible for about $96 \%$ of this total energy in the transport sector, consisting of both gasoline and diesel type vehicles. The increase in demand for cars is explainable by an expected increase in the population, as more and more people buy cars for private and commercial use, with a stupendous growth of online carhailing services like Uber and Bolt in the country recently [13]. Motorcycles and Rickshaws, which are popular in the Nigerian population for private and commercial use, are expected to cover only about $1 \%$ of the total energy demand in the transport sector by 2040 . The energy needs of other vehicles such as buses, trucks, agriculture machines, tractors, articulated vehicle and earth moving vehicle are expected to take the remaining $3 \%$ [5]. The above infers that alternative fuels such as biofuels in the transportation sector may go a long way to help reduce dependence on fossil fuel and thus give a significant reduction in the greenhouse gas emissions in Nigeria [14]. The growing Nigerian population has also exhibited a significantly increasing energy demand in all other sectors apart from transportation [15].

\subsection{A Search for a Sustainable Feedstock for Biofuel Production in Nigeria}

The total area of Nigeria is 92.4 million hectares, of which 79.4 million hectares are land while 13.0 million hectares covered with water [6]. The country has been classified to be among countries that have a high potential for bioenergy development, with about 72 million hectares of arable land available. About $60 \%$ of cultivable land is still vacant for out-growers to conveniently execute crop plantation to meet up with any feasible feedstock demand for biofuel production both for local consumption and exportation prospect [16]. Figure 2 is showing the land use for the year 2015 as recorded by Food and Agriculture Organization of the United Nations [17]. From the line of discuss above, it has become imperative to intensify research in search of the crops that can attract commercial production of biofuel to make a quick integration into the Nigerian biofuel market. This focus may engender the production of a particular type of biofuel that can be obtained from a viable feedstock that is predominant in nature in Nigerian soil.

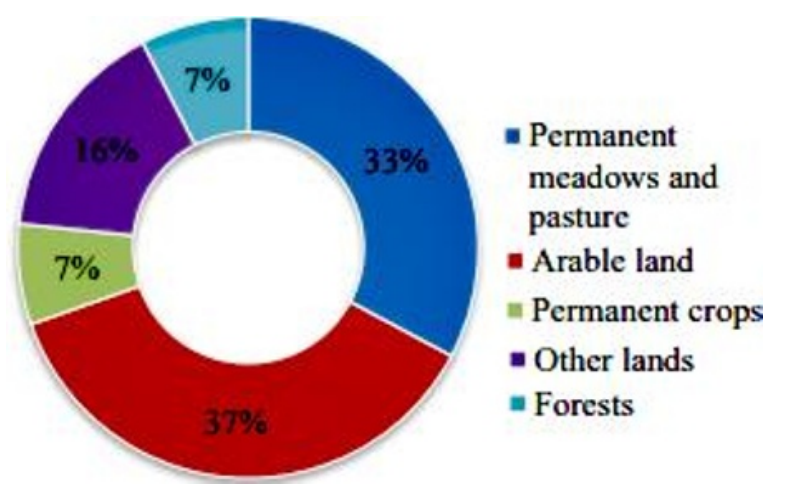

Fig. 2. Land use in Nigeria in 2015 [17]

Research had shown that the established biofuel feedstocks that has potential for commercial production in Nigeria includes Sweet Sorghum, Cassava, Sugarcane, Oil Palm, Soybean, Groundnut and Jatropha amongst others, although section 9.5 of the "Official Gazette of the Nigerian Bio-fuel Policy and Incentives" placed a caution on the use of Palm oil and Jatropha as biodiesel feedstock in Nigeria [18]. The author's attention had been drawn to the Oil Palm as it is one of the highest agricultural heritage of the country [19] and also by the fact that Oil Palm had been utilized for massive biofuel production particularly in Thailand, Malaysia and Indonesia; to the point of enormous exportation [20]. Table 1 shows the World palm oil production, which has Nigeria sitting at the top five. 
Table 1. World Palm Oil Production status [21]

\begin{tabular}{llc}
\hline Rank & \multicolumn{1}{c}{ Country } & $\begin{array}{c}\text { Production } \\
\text { (Million Tonnes) }\end{array}$ \\
\hline 1 & Indonesia & 33.4 \\
2 & Malaysia & 19.9 \\
3 & Thailand & 2.1 \\
4 & Colombia & 1.2 \\
5 & Nigeria & 0.9 \\
6 & Papua New Guinea & 0.5 \\
7 & Ecuador & 0.5 \\
8 & Guatemala & 0.5 \\
9 & Honduras & 0.4 \\
10 & Cote d'Ivoire & 0.4 \\
& Others* & 2.8 \\
\hline & Total & 62.3 \\
\hline
\end{tabular}

* Others includes Ghana, Brazil, Cameroon, Costa Rica, Congo, Philippines, and few others with minimal contributions [22].

On the global scene, Oil palm accounts for about $10 \%$ of biodiesel production and is proliferating. It is the most efficient and cheapest source of biodiesel yield per unit area compared to other oilseed crops such as soybean, rapeseed or sunflower [23]. Figure 3 presented some biodiesel feedstock from crop vegetable oil yield and their world plantation land area.

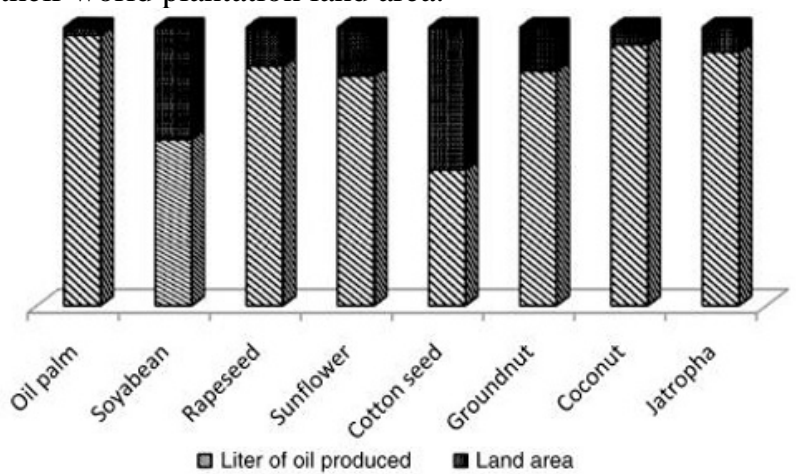

Fig. 3. Major Biodiesel feedstock crops' efficiency [24]

The average palm oil yield is about 3.62 tons /ha/year, compared with 0.4 for soybean oil, 0.46 for sunflower and 0.68 for rapeseed [21]. The booming palm oil biodiesel economy in countries like Indonesia and Malaysia would have been convincing that palm oil biodiesel can also be a pathway for Nigerian Biofuel industry owing to the fact that these two countries and Nigeria are among the world's largest producers of oil palm [25] [14]. Figure 4 shows the Malaysian palm biofuel production and exportation rate for eight years.

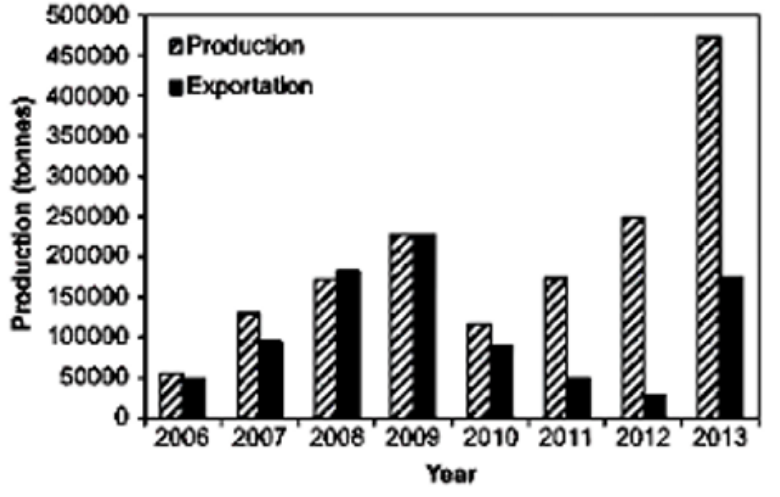

Fig. 4. The Malaysian palm biofuel production and exportation rate from 2006 to 2013 [21]

\section{Palm olein as a sustainable biodiesel feedstock in Nigeria: a promising balance to food-energy nexus}

The palm oil and palm olein are both gotten from a palm species called oil palm tree, which has been seen for over 5000 years in South-Eastern Asia, Africa and Latin America [26]. A hectare of oil palm plantation can produce ten times the value of oil that can be gotten from other leading oilseed crops [24]. Naturally, oil palm tree produces two kinds of oils: unrefined palm oil (UPO) gotten from the mesocarp and palm kernel oil from within the kernel [26]. UPO, in its natural state, has a brilliant orange colour because of the high level of carotene pigmentation and always remains in a semisolid state at ambient temperature. In its natural state, it is broadly used in the production of soap, margarine and vegetable shortenings [27]. The UPO is extracted directly from the ripened mesocarp under pressure and can be processed into refined palm oil which is usually referred to as the "red oil" for both household cooking and direct consumption [28]. When further refined at elevated pressure and temperature, it separates into palm stearine and palm olein [2]. The palm olein, when compared to palm oil, has exceptional attributes, which include the ability to remain totally in a liquid state at room temperature, exceptionally heat safe [27], opposes the arrangement of breakdown products when used for frying and an increment in timeframe for realistic usability [29]. Palm olein is presently gaining popularity for frying purposes because it is considered to have the highest quality level when compared to others [21] although the red oil is still the most prominent oil palm product consumed. Figure 5 shows all the extracts, byeproducts and wastes including Palm olein, that can be obtained from Oil Palm industry. 


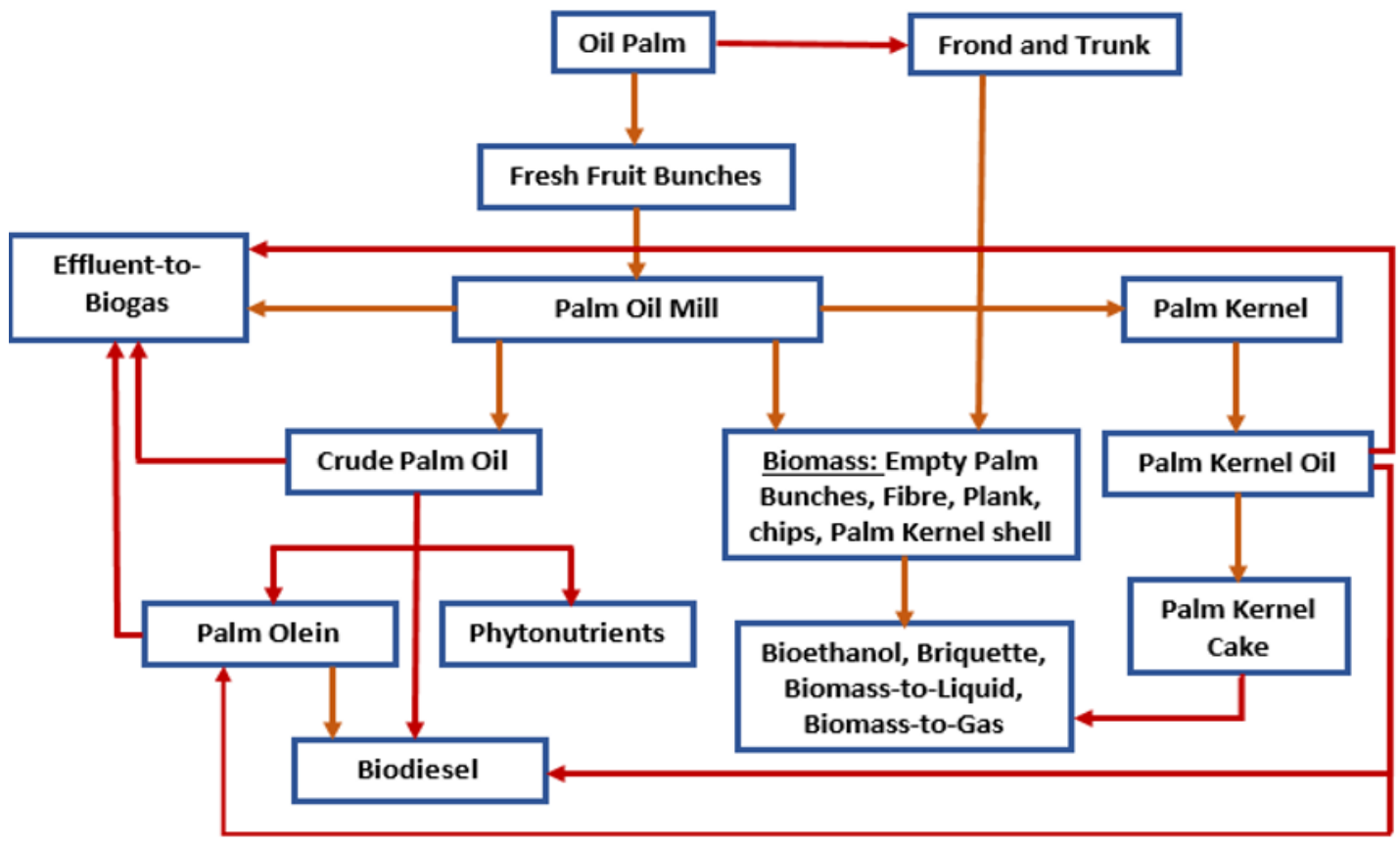

Fig. 5. A logical Renewable Energy Potential Analysis Model for Oil Palm industry [24] [30]-[34]

There has been a criticism that biofuels from crops like palm can cause a drag between the supply and demand of these crops which may invariably lead to scarcity of palm oil which is a predominantly cooking oil in Nigeria [35], [36]. But on a contrary opinion, in the palm oil industry, various types of by-products are produced in large quantities, in solid, liquid and gaseous form. It has been established that only $10 \%$ of the total biomass recovered from the palm oil farm is converted to edible oil with the remaining $90 \%$ as either by-products or wastes [37]. On an average estimation, a palm oil refining process could produce a total of $73 \%$ olein, $21 \%$ stearin, $5 \%$ palm fatty acid distillate (PFAD) and $0.5 \%$ gas effluent [37].

The locally available palm olein was considered a sustainable option for biodiesel production because palm olein could be extracted as a bye product of palm oil [38]. This indicates that there could be concurrent products of both food purposes as well as biofuel purpose from a single production process of oil palm. This was illustrated in figure 5 presenting a logical renewable energy potential analysis model for the Oil palm industry.

\section{Conclusion}

Despite the desperate need to promote energy security and low-level greenhouse gas (GHG) emission, Nigeria had made little progress towards developing her biofuel industry amidst many unimplemented policies. By a direct comparative analysis, Nigerian oil palm industry has been tipped to have a prospect for a commercialscale biofuel production that can serve as both affordable clean fuel for her populace and also as a source of national exportation revenue. Oil palm has been projected as having the capacity of becoming a valuable commodity that can meet global demand in the culinary field and at the same time contribute to global energy security thus balancing the food-fuel nexus. On this leverage, there is a feasibility of commercial-scale production of quality biodiesel from local oil palm industries without affecting the availability of edible palm oil in Nigeria. The Nigerian government and stakeholders are hereby encouraged to latch onto the energy prospect of oil palm bioresources to contribute to solving her energy poverty issues.

The authors wish to gratefully acknowledge the funding provided by Covenant University, Ota, Nigeria.

\section{References}

1. T. Mamudu, A.O. and Olukanmi, Int. J. Civ. Eng. Technol., 10, 1, pp. 2613-2623, (2019).

2. H. Wijaya, Y. Arkeman, and E. Hambali, Agric. Eng. Int. CIGR J., Special, pp. 268-282, (2017).

3. P. F. Tarbuka, O. Onocha, and E. O. Ohimor, Int. J. Res. Eng. Innov., 1, 4, (2017).

4. O. O. Olatunji, O. Ayo, S. Akinlabi, F. Ishola, M. N., and P. Adedeji, J. Clean. Prod., 238, p. 117937., (2019).

5. N. V. Emodi, Energy Policies for Sustainable Development Strategies. Springer, (2016).

6. J. Agba, A. M. O., Ushie, M. E., Abam, F. I., Agba, M. S., \& Okoro, Eur. J. Sci. Res., 40, 3, pp. 441-449, (2010).

7. E. I. Ohimain, Energy Policy, 54, pp. 352-359, (2013).

8. O. Osunmuyiwa, Environ. Policy Gov., 27, 6, pp. 632-646, (2017).

9. A. S. Yusuff, M. A. Lala, L. T. Popoola, and O. A. Adesina, SN Appl. Sci., 1, 4, p. 357, (2019).

10. A. S. Sambo, in World Future Council Workshop on Renewable Energy Policies, (2009). 
11. D. Dias, A. P. Antunes, and O. Tchepel, Sustainability, 11, p. 2902, (2019).

12. O. A. Towoju and S. O. Jekayinfa, J. Eng. Sci., 6, 1, (2019).

13. K. Meagher, in UNRISD Conference, (2018).

14. J. Ben-iwo, V. Manovic, and P. Longhurst, Renew. Sustain. Energy Rev., 63, pp. 172-192, (2016).

15. F. A. Ishola, O. O. Olatunji, O. O. Ayo, S. A. Akinlabi, P. A. Adedeji, and A. O. Inegbenebor, Procedia Manuf., 35, pp. 1165-1171, (2019).

16. S. O. Oyedepo, O. P. Babalola, S. C. Nwanya, O. Kilanko, A. O. Abidakun, and O. L. Agberegha, J. Sustain. Dev. Res., 2, 4, (2018).

17. FAO, (2018).

18. O. A. (GGM R.-N. Anyaoku, (2007).

19. E. . Ohimain, Renew. Sustain. Energy Rev., 22, pp. 246-256, (2013).

20. R. Tambun, O. N. Gusti, M. A. Nasution, and R. P. Saptawaldi, J. Bahan Alam Terbarukan, 6, 1, pp. 5055, (2017).

21. M. K. Lam, N. A. Jamalluddin, and K. T. Lee, in Biofuels: Alternative Feedstocks and Conversion Processes for the Production of Liquid and Gaseous biofuels, 2nd ed., Elsevier Inc., (2019).

22. M. H. Mosarof et al., Energy Convers. Manag., 105, pp. 617-629, (2015).

23. K. R. Szulczyk and R. A. Khan, J. Clean. Prod., 203, pp. 260-272, (2018).

24. K. T. Lee and C. Ofori-boateng, Sustainability of Biofuel Production from Oil Palm Biomass. (2013).
25. D. J. Murphy, J. Oil Palm Res., 26, 1, pp. 1-24, (2014).

26. Gourichon H, Rome, (2013).

27. O. I. Mba, M. J. Dumont, and M. Ngadi, Food Biosci., 10, pp. 26-41, (2015).

28. C. W. Puah, Y. M. Choo, A. N. Ma, and C. H. Chuah, 19, 2, pp. 31-34, (2007).

29. H. A. Hashem, M. Shahat, S. A. El-Behairy, and A. Sabry, Middle East J. Appl. Sci., 7, 1, pp. 68-79, (2017).

30. S. Bajgain, Nepal, (2008).

31. J. Mahmud, E. Hambali, Y. Arkeman, and A. R. Hoetman, in International Conference on Soft Computing, Intelligence Systems, and Information Technology, (2015).

32. H. E. Y. M. Tuggar, in 12th German-African Energy Forum, (2018).

33. M. Ali, M. A. Farid, Y. Shirai, H. Ariffin, M. R. Othman, and M. Y. H. Mohd Hafif Samsudin, Biotechnology, 1800394, (2019).

34. N. Izzah, H. A. Aziz, and M. M. Hana, Renew. Energy, 145, pp. 847-857, (2020).

35. O. S. Olarinde and D. S. Olawuyi, 2, October, pp. 224-242, (2013).

36. T. E. Odetoye, E. O. Ajala, and J. O. Titiloye, FUOYE J. Eng. Technol., 4, 1, pp. 87-91, (2019).

37. K. Zahan and M. Kano, Energies, 11, 8, pp. 1-25, (2018).

38. N. A. Pannilawithana and H. M. K. K. Pathirana, J. Oil Palm Res., 29, June, pp. 267-277, (2017). 